\title{
Bauran Pemasaran Susu Sapi dan Susu Kambing Segar di Kota Padang
}

\section{Marketing Mix of Dairy Milk and Goat Milk in Padang}

\author{
W. Sartika* dan J. Hellyward \\ Fakultas Peternakan Universitas Andalas, Padang, 25163 \\ *E-mail: winda_pdg@yahoo.com \\ (Diterima: 7 Agustus 2017; Disetujui: 20 September 2017)
}

\begin{abstract}
ABSTRAK
Pemasaran merupakan ujung tombak dalam suatu kegiatan usaha. Proses pengambilan keputusan untuk membeli suatu produk dipengaruhi oleh beberapa faktor dalam bauran pemasaran (marketing mix) yang terdiri dari produk, harga, promosi, dan tempat. Penelitian ini bertujuan untuk mengetahui dan menganalisis pengaruh bauran pemasaran (4P) terhadap kepuasan pembelian susu sapi dan susu kambing segar di Kota Padang. Lokasi penelitian berada di Kota Padang dimana metode penelitian yang digunakan adalah metode survey. Variabel yang digunakan adalah Produk (bentuk kemasan, kepraktisan kemasan, bahan kemasan, aroma susu, label kadaluarsa), Harga (harga produk, kesetujuan harga), Promosi (daya tarik iklan yang dilakukan dan sumber informasi produk), Tempat dan pelayanan (kenyamanan tempat, keramahan, dan letak lokasi). Analisa data dilakukan secara deskriptif kuantitatif dan kualitatif dengan bantuan program SPSS. Hasil penelitian menunjukkan bahwa bauran pemasaran susu sapi yang terdiri dari produk, harga, promosi dan tempat (4P) menghasilkan nilai R2 sebesar 41,2\%. Hal ini menunjukkan bahwa variabel $4 \mathrm{P}$ hanya berpengaruh sebesar $41,2 \%$ terhadap kepuasan konsumen dalam melakukan pembelian susu sapi segar sedangkan sisanya 58,8\% dipengaruhi oleh faktor-faktor lain diluar 4P. Sedangkan untuk pembelian susu kambing, R2 sebesar $22,7 \%$ artinya variabel produk, harga, promosi dan tempat hanya mampu mempengaruhi kepuasan konsumen terhadap pembelian susu kambing sebesar 22,7\%.
\end{abstract}

Kata kunci: bauran pemasaran, susu sapi, susu kambing

\section{ABSTRACT}

Marketing is the spearhead in a business activity. The decision making process to buy a product is influenced by several factors in the marketing mix, which consist of product, price, promotion, and place. This study aims to determine and analyze the influence of marketing mix (4P) on satisfaction of purchase of cow's milk and fresh goat milk in Padang City. The research location is in Padang City where the research method used is survey method. Variables used are Product (packaging form, practicality of packaging, packaging material, aroma of milk, expired label), Price (product price, price approval), Promotion (attractiveness of advertisement made and product information source), Place and service, friendliness, and location). Data analysis was done descriptively quantitative and qualitative with the help of SPSS program. The results showed that the marketing mix of cow's milk consisting of product, price, promotion and place $(4 P)$ resulted in $R 2$ value of $41.2 \%$. It shows that $4 P$ variable only influence $41.2 \%$ to consumer satisfaction in buying fresh cow's milk while the rest $58.8 \%$ influenced by other factors outside $4 P$. As for the purchase of goat milk, R2 of 22.7\% means that product variables, prices, promotions and places are only able to affect customer satisfaction of goat milk purchase by $22.7 \%$.

Keywords: marketing mix, dairy milk, goat's milk

\section{PENDAHULUAN}

Daging, telur dan susu merupakan jenis protein hewani yang berasal dari usaha peternakan yang sampai saat ini terus menjadi perhatian pemerintah guna untuk meningkatkan produktivitasnya. Diantara ketiga protein hewani tersebut, susu merupakan jenis protein hewani yang sebagian besar berasal dari luar (impor). 
Sumatera Barat merupakan salah satu wilayah yang sangat potensial guna untuk pengembangan ternak penghasil susu baik itu sapi perah maupun kambing perah. Usaha peternakan sapi perah untuk wilayah Kota Padang memang masih sangat sedikit. Salah satu daerah pengembangan ternak sapi perah yang ada di Kota Padang terletak di Kecamatan Pauh, tepatnya di Kelurahan Limau Manis. Ternak sapi yang dipelihara oleh peternak awalnya berupa bantuan dari pemerintah dan sampai saat ini ternak tersebut masih dipelihara dengan baik oleh peternak. Hasil usaha peternakan sapi perah ini sudah bisa membantu peternak untuk memenuhi kebutuhan hidupnya. Hanya saja kadang-kadang peternak terkendala dengan pemasaran susu sapi segar tersebut. Teknologi yang kurang memadai membuat peternak harus segera memasarkan hasil produksinya tersebut.

Selain ternak sapi perah, di Kota Padang juga terdapat usaha peternakan kambing perah yang sampai saat ini menunjukkan perkembangan yang cukup baik. Usaha peternakan kambing perah di Kota Padang salah satunya berada di daerah Gunung Pangilun. Selain susu sapi, masyarakat juga mulai menyadari bahwa susu kambing dapat memberikan manfaat yang tidak kalah pentingnya bagi kesehatan. Peluang inilah yang menjadi motivasi peternak untuk mengembangkan usaha peternakan kambing perah. Hasil produksi kambing perah berupa susu segar biasanya dipasarkan langsung oleh peternak. Keterbatasan pengetahuan tentang pemasaran membuat peternak melakukan penjualan secara langsung kepada konsumen.

Pemasaran merupakan ujung tombak dalam suatu kegitatn usaha. Pemasaran yang tidak baik dapat merugikan usaha tersebut. Bauran pemasaran merupakan seperangkat alat yang digunakan untuk mencapai tujuan pemasaran dalam rangka memenuhi kepuasan pelanggan. Proses pengambilan keputusan untuk membeli suatu produk akan dipengaruhi oleh beberapa faktor bauran pemasaran (marketing mix) yang terdiri dari produk, harga, promosi, dan tempat. Tetapi tidak seluruh variabel bauran pemasaran tersebut dipertimbangkan oleh konsumen dalam memutuskan untuk membeli suatu produk. Karena itu penulis tertarik untuk melakukan penelitian dengan tujuan untuk mengetahui dan menganalisis faktor-faktor apa saja yang mempengaruhi pembelian susu sapi dan susu kambing ditinjau dari faktor bauran pemasaran (4P).

\section{METODE}

Bauran pemasaran (Marketing Mix) merupakan kumpulan alat pemasaran taktis terkendali - produk, harga, tempat, dan promosi yang dipadukan perusahaan untuk menghasilkan respons yang diinginkan di pasar sasaran. Bauran pemasaran terdiri dari semua hal yang dapat dilakukan perusahaan untuk mempengaruhi permintaan akan produknya yang terdiri dari "empat P" yaitu: (Kotler dan Amstrong, 2008)

1. Produk (product), kombinasi barang dan jasa yang ditawarkan perusahaan kepada pasar sasaran meliputi : ragam, kualitas, desain. fitur, nama merek, dan kemasan ;

2. Harga (price), adalah sejumlah uang yang harus dibayarkan pelanggan untuk memperoleh produk meliputi: daftar harga, diskon potongan harga, periode pembayaran, dan persyaratan kredit ;

3. Tempat (place), kegiatan perusahaan yang membuat produk tersedia bagi pelanggan sasaran meliputi: Lokasi, saluran distribusi, persediaan, transportasi dan logistik ;

4. Promosi (promotion) berarti aktivitas yang menyampaikan manfaat produk dan membujuk pelanggan membelinya meliputi : Iklan dan promosi penjualan.

Program pemasaran yang efektif harus dapat memadukan semua elemen bauran pemasaran ke dalam suatu program pemasaran terintegrasi yang dirancang untuk mencapai tujuan pemasaran perusahaan dengan menghantarkan nilai bagi konsumen.

Penelitian ini dilaksanakan pada usaha 
peternakan kambing perah yang berada di daerah Gunung Pangilun dan peternakan sapi perah yang berada di Kelurahan Limau Manis, Kota Padang. Lokasi penelitian dipilih secara purposive (sengaja). Pada penelitian ini ada 4 variabel yang diukur, yaitu: (Sagantoro et al., 2013)

1. Produk (bentuk kemasan, kepraktisan kemasan, bahan kemasan, aroma, label kadaluarsa)

2. Harga (harga produk, kesetujuan harga),

3. Promosi (daya tarik iklan yang dilakukan dan sumber informasinya),

4. Tempat dan pelayanan (kenyamanan tempat, keramahan, dan lokasi).

Analisa data untuk tujuan pertama dilakukan secara deskriptif kualitatif dengan bantuan kuisioner. Sedangkan tujuan keduan dianalisa dengan bantuan program SPSS 16.0 dan secara matematis model analisis faktornya adalah sebagai berikut :

$$
\mathrm{Y}=\mathrm{a}+\mathrm{b} 1 \mathrm{X} 1+\mathrm{b} 2 \mathrm{X} 2+\mathrm{b} 3 \mathrm{X} 3+\mathrm{b} 4 \mathrm{X} 4
$$

Keterangan :

\begin{tabular}{|c|c|}
\hline Y & $=$ Variabel dependen \\
\hline $\mathrm{a}$ & $=$ Konstanta \\
\hline b1,b2,..b5 & $=$ Koefisien \\
\hline $\mathrm{X} 1$ & $=$ Produk \\
\hline $\mathrm{X} 2$ & $=$ Harga \\
\hline $\mathrm{X} 3$ & $=$ Promosi \\
\hline $\mathrm{X} 4$ & $=$ Tempat dan Pelayanan \\
\hline
\end{tabular}

\section{HASIL DAN PEMBAHASAN}

\section{Bauran Pemasaran Susu Sapi}

Usaha peternakan sapi perah Harapan Saiyo telah berdiri sejak tahun 2011 melalui program SMD. Pada awal pendirian jumlah sapi yang dimiliki oleh peternak berjumlah 16 ekor. Usaha sapi perah yang dikelola kelompok ini sekarang telah berubah pengelolaannya menjadi pengelolaan secara individu. Pak Jamaris selaku ketua kelompok Harapan Saiyo berinisiatif untuk membagi ternak sapi yang dipelihara dikarenakan masalah sistem pengelolaan sapi yang sulit untuk diselesaikan dengan para anggotanya. Saat penelitian ini dilakukan, jumlah sapi yang dipelihara oleh
Pak Jamaris berjumlah 5 ekor ( 3 induk dan 2 ekor anak). Jumlah ternak sapi yang sedang laktasi sekarang adalah 3 ekor degan jumlah susu yang dihasilkan sekitar 18-20 liter/hr.

Faktor-faktor dalam bauran pemasaran berupa produk, harga, promosi dan tempat (4P) mampu mempengaruhi pembelian susu sapi dengan nilai $\mathrm{R}^{2}$ sebesar $41,2 \%$. Hal ini menunjukkan bahwa variabel $4 \mathrm{P}$ hanya berpengaruh sebesar $41,2 \%$ terhadap kepuasan konsumen dalam melakukan pembelian susu sapi segar sedangkan sisanya $58,8 \%$ dipengaruhi oleh faktor-faktor lain. Produk susu sapi yang dijual berupa susu sapi segar murni tanpa pengolahan lebih lanjut. Nastiti dan Martoatmodjo (2007) mengyatakan bahwa bauran pemasaran berpengaruh langsung terhadap peningkatan kepuasan konsumen, artinya apabila kualitas bauran pemasaran meningkat makan kepuasan konsumen juga akan meningkat. Dengan demikian, faktor-faktor dalam bauran pemasaran sangat mempengaruhi permintaan terhadap susu sapi yang dijual. Menurut Rahadja dan Manurung (2002) salah satu faktor yang mempengaruhi permintaan adalah selera. Selera atau kebiasaan konsumen juga dapat mempengaruhi permintaan suatu barang. Selera konsumen dapat disebabkan oleh perubahan umur, perubahan pendapatan, perubahan lingkungan, dan sebagainya. Susu sapi murni memiliki bau khas yang kurang disukai masyarakat oleh karena itu pengolahan lebih lanjut diharapkan dapat membantu penjualan susu sapi ini. Peternak juga melakukan penjualan susu sapi secara langsung kepada konsumennya hal ini serupa dengan penelitian. Kegiatan promosi belum dilakukan oleh peternak guna untuk meningkatkan penjualan susu sapinya, sedangkan menurut Sukotjo dan Radi (2010), promosi merupakan variabel paling dominan terhadap keputusan pembelian. Berdasarkan hasil pengolahan data dengan SPSS diketahui bahwa nilai $\mathrm{F}$ hitung didapatkan 2,278 dan angka ini lebih kecil dari angka F-tabel. Hal ini menunjukkan bahwa pengujian secara bersama-sama variabel produk, 
Tabel 1. Hasil SPSS susu sapi segar.

\begin{tabular}{|l|r|r|r|r|}
\multicolumn{5}{|c|}{ Model Summary $^{\mathbf{b}}$} \\
\hline Model & \multicolumn{1}{|c|}{ R } & \multicolumn{1}{c|}{ R Square } & Adjusted R Square & Std. Error of the Estimate \\
\hline 1 & $.642^{\mathrm{a}}$ & .412 & .231 & 3.76837 \\
\hline
\end{tabular}

a. Predictors: (constant) Place, Promosi, Price, Produk...

b. Dependent Variable: Kepuasan

ANOVA $^{b}$

\begin{tabular}{|l|l|r|r|r|r|r|}
\hline \multicolumn{1}{|l|}{ Model } & Sum of Squares & df & Mean Square & F & Significance \\
\hline 1 & Regression & 129.392 & 4 & 32.348 & 2.278 & $.116^{\mathrm{a}}$ \\
& Residual & 184.608 & 13 & 14.201 & & \\
& Total & 314.000 & 17 & & & \\
\hline
\end{tabular}

a. Predictors: (constant) Place, Promosi, Price, Produk...

b. Dependent Variable: Kepuasan

\begin{tabular}{|c|c|c|c|c|c|c|}
\hline \multicolumn{7}{|c|}{ Coefficients $^{\mathrm{a}}$} \\
\hline \multirow{2}{*}{\multicolumn{2}{|c|}{ Model }} & \multicolumn{2}{|c|}{ Unstandardized Coefficients } & $\begin{array}{l}\text { Standardized } \\
\text { Coefficients }\end{array}$ & \multirow[b]{2}{*}{$\mathrm{t}$} & \multirow[b]{2}{*}{ Significance } \\
\hline & & $\mathrm{B}$ & Std. Error & Beta & & \\
\hline & (Constant) & 23.711 & 13.777 & & 1.721 & .109 \\
\hline & Produk & .221 & .815 & .065 & .271 & .790 \\
\hline & Price & 1.398 & .693 & .457 & 2.018 & .065 \\
\hline & Promosi & 1.903 & 1.060 & .399 & 1.795 & .096 \\
\hline & Place & -.201 & 1.052 & -.048 & -.192 & .851 \\
\hline
\end{tabular}

harga, promosi dan tempat belum dapat mempengaruhi kepuasan konsumen dalam melakukan pembelian susu sapi. Persamaan regresinya didapatkan sebagai berikut :

$$
\mathrm{Y}=23,71+0,22 \mathrm{X} 1+1,39 \mathrm{X} 2+1,90 \mathrm{X} 3-0,2 \mathrm{X} 4
$$

Persamaan regresi untuk susu sapi segar menunjukkan angka yang positif untuk variabel produk, harga dan promosi, itu artinya setiap tindakan yang dilakukan oleh produsen yang berkaitan dengan ketiga variabel itu akan memberikan pengaruh yang positif terhadap tingkat kepuasan konsumen. Sedangkan variabel tempat menunjukkan angka yang negatif, hal ini mengartikan bahwa lokasi usaha peternakan susu sapi yang cukup jauh masih membuat konsumen tidak puas dalam melakukan pembelian. Lokasi yang jauh dan susah dijangkau membuat konsumen merasa kesulitan untuk mendapatkan susu sapi tersebut. Promosi belum dilakukan dengan baik oleh peternak, menurut Swasta (2004), tujuan utama promosi adalah menginformasikan, mempengaruhi dan membujuk serta mengingatkan pelanggan sasaran tentang pemasaran dan bauran pemasaran. Promosi yang di lakukan dengan cara pemberian diskon, brosur yang menarik serta melalui SPG atau karyawan.

\section{Bauran Pemasaran Susu Kambing}

Usaha Peternakan kambing perah merupakan usaha yang sangat potensial untuk dikembangkan. Susu yang merupakan hasil utama usaha ini sangat bermanfaat bagi pemenuhan kebutuhan protein hewani dan juga kesehatan. Usaha peternakan kambing Perah El Fitra pertama kali didirikan dengan latar belakang kesehatan keluarga khusunya suami ibu Yelita sebagai pemilik ternak. Keluarga Ibu Yelita sudah lama mengkonsumsi susu kambing dan sudah merasakan manfaatnya bagi kesehatan mereka. Berdasarkan hal tersebut maka keluarga ini berniat untuk melanjutkan memelihara kambing perah. Moeljanto dan Wiryanta (2002) mengatakan bahwa susu kambing merupakan satu-satunya susu hewan yang bisa dikonsumsi tanpa 
Tabel 2. Hasil SPSS susu kambing segar.

\begin{tabular}{|l|r|r|r|r|}
\multicolumn{7}{|c|}{ Model Summary $^{\mathbf{b}}$} \\
\hline Model & \multicolumn{1}{|c|}{ R } & R Square & Adjusted R Square & $\begin{array}{c}\text { Std. Error of the } \\
\text { Estimate }\end{array}$ \\
\hline 1 & $.476^{\mathrm{a}}$ & .227 & .127 & 3.370 \\
\hline
\end{tabular}

a. Predictors: (constant) Tempat, Harga, Promosi, Produk...

b. Dependent Variable: Kepuasan

\begin{tabular}{|ll|r|r|r|r|r|}
\hline \multicolumn{1}{|c|}{ ANOVA $^{\mathbf{b}}$} \\
\hline Model & & Sum of Squares & df & Mean Square & \multicolumn{1}{c|}{ F } & \multicolumn{1}{c|}{ Significance } \\
\hline 1 & Regression & 103.197 & 4 & 25.799 & 2.272 & $.084^{\mathrm{a}}$ \\
& Residual & 352.025 & 31 & 11.356 & & \\
& Total & 455.222 & 35 & & & \\
\hline
\end{tabular}

b. Dependent Variable: Kepuasan

\begin{tabular}{|c|c|c|c|c|c|c|}
\hline \multicolumn{7}{|c|}{ Coefficients ${ }^{\mathrm{a}}$} \\
\hline \multirow{2}{*}{\multicolumn{2}{|c|}{ Model }} & \multicolumn{2}{|c|}{ Unstandardized Coefficients } & \multirow{2}{*}{$\begin{array}{c}\begin{array}{c}\text { Standardized } \\
\text { Coefficients }\end{array} \\
\text { Beta } \\
\end{array}$} & \multirow[b]{2}{*}{$\mathrm{t}$} & \multirow[b]{2}{*}{ Significance } \\
\hline & & $\mathrm{B}$ & Std. Error & & & \\
\hline 1 & (Constant) & 29.112 & 8.654 & & 3.364 & .002 \\
\hline & Produk & .471 & .327 & .283 & 1.440 & .160 \\
\hline & Harga & .902 & .507 & .283 & 1.780 & .085 \\
\hline & Promosi & 1.062 & .523 & .334 & 2.030 & .051 \\
\hline & Tempat & -.286 & .554 & -.104 & -.516 & .609 \\
\hline
\end{tabular}

dimasak terlebih dahulu seperti ASI (Air Susu Ibu).

Usaha peternakan kambing El Fitra berdiri pada akhir tahun 2012 dengan jumlah awal ternak kambing yang dipelihara adalah 3 ekor induk dan 1 ekor anak kambing. Bibit kambing dibeli di Maxwell Farm, yaitu peternakan kambing yang berada di Sungai Sapih, Padang. Sedangkan ternak kambing jantan di beli dari Payakumbuh. Setelah 4 tahun berdiri usaha ini semakin berkembang dan saat ini jumlah ternak kambing di El Fitra Farm sudah mencapai 30 ekor dengan rincian 9 ekor induk, 3 ekor pejantan, dan sisanya 18 ekor anakan. Untuk memenuhi kebutuhan pakan kambing, biasanya peternak memberikan dan mencarikan rumput setiap hari (Sartika, 2016).

Pakan ternak kambing yang diberikan oleh peternak adalah daun singkong (silase) ditambah dengan konsentrat (ampas tahu, bungkil sawit dan dedak). Pakan yang bergizi dapat meningkatkan jumlah produksi susu kambing yang dihasilkam. Susu kambing yang dihasilkan saat ini rata-rata mencapat 5 liter/ hari (murni). Susu yang dihasilkan biasanya langsung dipacking atau dikemas. Ada dua ukuran kemasan yang dijual oleh Peternakan kambing El Fitra, pertama susu kambing yang berukuran $200 \mathrm{ml}$ dengan harga $\mathrm{Rp} 12.000$ / pack sedangkan untuk ukuran yang lebih besar $330 \mathrm{ml}$ biasanya dijual dengan harga $60.000 /$ botol.

Berdasarkan Tabel 2 terlihat bahwa R2 untuk susu kambing segar adalah $22,7 \%$ itu artinya variabel dalam marketing mix seperti produk, harga, promosi dan tempat hanya mampu mempengaruhi kepuasan konsumen sebesar $22,7 \%$ dari pembelian yang mereka lakukan. Faktor lain sebesar $77,3 \%$ lebih berpengaruh terhadap kepuasan konsumen dalam melakukan pembelian susu kambing segar. Faktor lain yang dapat mempengaruhi pembelian susu kambing berupa pendapatan konsumen ataupun selera konsumen. Sartika dan Iskandar (2016) tataniaga susu kambing El Fitra Farm terdiri dari dua saluran, saluran pertama : produsen langsung ke konsumen dan pada saluran kedua yaitu dari produsenpengecer-konsumen. Margin pemasaran untuk 
saluran tataniaga ke dua sebesar Rp 10.000/ liter dan $\mathrm{Rp}$ 20.000/liter (dua pedagang dengan harga yang berbeda). Rantai tataniaga saluran kedua dinilai kurang efektif karena belum melaksanakan fungsi pemasaran dengan baik. Dari penelitian tersebut dapat terlihat bahwa pemasaran susu kambing pada usaha peternakan ini masih perlu untuk ditata lebih baik.

Sedangkan dari persamaan regresi untuk variabel produk, harga, promosi memberikan nilai postif untuk kepuasan konsumen dalam pembelian susu kambing. Itu berarti bahwa setiap tindakan positif yang dilakukan oleh peternak terhadap produk, harga atau promosi mampu memberikan kepuasan terhadap konsumennya. Masrita (2013) menyatakan bahwa variabel harga berpengaruh signifikan terhadap keputusan pembelian, selain itu harga juga menjadi indikator kualitas dimana suatu produk dengan kualitas tinggi akan berani dipatok dengan harga yang tinggi pula. Sedangkan tempat atau place menunjukkan angka yang negatif, hal ini artinya perlu adanya perbaikan dari sisi tempat untuk penjualan susu kambing tersebut. Penjualan susu kambing segar masih dilakukan secara tradisional, pembelian masih dilakukan langsung ke lokasi kandang peternak. Lokasi kandang yang cukup jauh dan kurang strategis membuat konsumen cukup kesulitan untuk mendapatkan atau membeli susu kambing. Hal ini serupa dengan Arviansyah et al.(2015) bahwa pemasaran susu kambing Peranakan Etawa (PE) masih cukup sulit, hal ini diketahui dengan cara peternak hanya menunggu pembeli yang datang ke lokasi peternakan untuk membeli dan jika tidak ada pembeli maka susu kambing PE hanya tersimpan dan dikonsumsi sendiri oleh peternak.

$\mathrm{Y}=29,11+0,47 \mathrm{X} 1+0,90 \mathrm{X} 2+1,06 \mathrm{X} 3-0,29 \mathrm{X} 4$

Berdasarkan hasil penelitian terlihat bahwa faktor-faktor lain diluar bauran pemasaran (produk, harga, tempat dan promosi) masih memiliki pengaruh yang besar terhadap penjualan susu sapi dan susu kambing segar di Kota Padang.

\section{KESIMPULAN}

Bauran pemasaran susu sapi yang terdiri dari produk, harga, promosi dan tempat (4P) mampu mempengaruhi pembelian susu sapi dengan nilai R2 sebesar $41,2 \%$ sisanya $58,8 \%$ dipengaruhi oleh faktor-faktor lain diluar 4P dimana faktor yang signifikan mempengaruhi pembelian adalah harga dan promosi. Sedangkan untuk pembelian susu kambing, faktor dalam bauran pemasaran yang berpengaruh dalam pembelian adalah harga dan promosi dengan nilai R2 sebesar $22,7 \%$.

\section{DAFTAR PUSTAKA}

Arviansyah, R., S. Widjaya dan S. Suriaty. 2015. Analisis Pendapatan dan Sistem Pemasaran Susu Kambing di Desa Sungai Langka Kec. Gedung Tataan Kab. Pesawaran. Jurnal Ilmu-Ilmu Agribisnis (JIIA) Vol. 3 No. 4, hal:363369

Kotler, P. dan G. Armstrong. 2008. PrisnsipPrinsip Pemasaran, edisi 12. Penerbit Erlangga. Jakarta.

Masrita. 2013. Pengaruh Bauran Pemasaran Terhadap Keputusan Pembelian Batik Jambi (Suatu Studi di Show Room Dekranasda Prov. Jambi), Jurnal Dinamikan Manajemen, Vo. 1 No.3, Hal 168-182

Moeljanto, R. D. dan B. T. W. Wiryanta. 2002. Khasiat dan Manfaat Susu Kambing : Susu Terbaik dari Hewan Ruminansia. PT Agromedia Pustaka, Jakarta.

Nastiti, A. dan S. Martoatmodjo. 2007. Pengaruh Bauran Pemasaran terhadap Keputusan Konsumen dengan Perilaku Konsumen sebagai Variabel Intervening. Jurnal Akuntansi, Manajemen Bisnis dan Sektor Publik, Vol.3 No. 3 hal:265-287.

Rahardja, P. dan M. Manurung. 2002. Pengantar Ilmu Ekonomi; Makro dan Mikro, LP FE UI, Jakarta. 
Sagantoro, S. R., Hartono dan U. H. Dwi. 2013. Analisis Bauran pemasaran dalam Pembelian Susu Pasteurisasi. Universitas Brawijaya. Malang.

Sartika, W. dan I. Iskandar. 2017. Analisis Tataniaga Susu Kambing El Fitra Farm di Kota Padang. Prosiding Seminar Nasional PERSEPSI III: Pengembangan Agribisnis Peternakan untuk Memperkuat Ekonomi Perdesaan di Indonesia. Denpasar.

Sartika, W. 2016. Identifikasi Keberlanjutan Peternakan Susu Kambing El Fitra di Kota Padang. Prosiding Seminar
Nasional PERTETA:Teknik Pertanian

Untuk Mendukung Kemandirian Pangan Berbasis Kearifan Lokal. Padang.

Sukotjo, H. dan S. A. Radi. 2010. Analisa Marketing Mix-7P (Product, Price, Promotion, Place, Participant, Process and Physical Evidence) terhadap Keputusan Pembelian Produk Klinik Kecantikan Teta di Surabaya. Jurnal Mitra Ekonomi dan Manajemen Bisnis, Vol. 1 No. 2 hal 216-226

Swasta, B. 2004. Pengantar Bisnis Modern. Edisi Ketiga. Penerbit Liberty. Yogyakarta. 